\title{
Characterization of the ecosystem and the status of phytoplankton populations in the Alboran Sea and the Algerian Basin from 2013 to 2015 during the spring season
}

\author{
Mustapha Boudjenah
}

CNRDPA / National Center for Research and Development of Fisheries and Aquaculture, 11 Boulevard Amirouche Bou-Ismail, Tipaza, Algeria; e-mail: boudjenahmust@yahoo.fr

\begin{abstract}
Knowledge of the taxonomic composition of phytoplankton communities is necessary for monitoring the productivity of an environment. It is through the understanding of the mechanisms, which promote the succession within phytoplankton populations, that we can estimate the productive capacities of the studied environments. The main purpose of this study is to make a quantitative and qualitative assessment, in order to explore the diversity of the phytoplankton community and the differences that exist between the Alboran Sea and the Algerian Basin, which will allow us to decide about the general state of the phytoplankton ecosystem on the Algerian coast. We made an assessment of the environmental factors that affect the structure and dynamics of phytoplankton communities; we recorded a mean seasonal temperature and salinity, respectively, on the Algerian coasts of about $15.76 \pm 0.60$ ${ }^{\circ} \mathrm{C}$ and $36.48 \pm 0.3 \mathrm{PSU}$ and we did not note any significant differences between the Alboran Sea and the Algerian Basin. Mean nutrients concentrations were recorded as follows: nitrates of $0.273 \pm 0.130 \mu \mathrm{mol} / 1$; nitrites of $0.085 \pm 0.065 \mu \mathrm{mol} / 1$; phosphorus, of $0.286 \pm 0.395$ $\mu \mathrm{mol} / 1$ and silicates of $0.375 \pm 0.366 \mu \mathrm{mol} / 1$, in the Algerian Basin and the Alboran Sea. We notice a decreasing gradient from West to East. We also identified and determined the phytoplankton species that describe the diversity of populations within the community; 361 species, comprising several genders, have been identified. Dinoflagellates are the most represented with $60.11 \%$ of species, diatoms represent $38.50 \%$ and other species represent only $1.39 \%$.
\end{abstract}

KEY WORDS Phytoplankton; Alboran Sea; Algerian Basin; environmental factors.

Received 10.03.2021; accepted 04.08.2021; published online 22.11.2021

\section{INTRODUCTION}

Phytoplankton groups and their compositions form under the influence of the physical, chemical and biological processes of the environments. At all time and space speeds, those fluctuations are, from a few minutes to a few million years, from a millimeter to a thousand kilometers (Haury et al., 1978).

The variations are more important in the Mediterranean, which is a semi-closed sea with high popular density, with more than 150 million people on $46,000 \mathrm{~km}$ of coastline, residing in multiple agglomerations (Marseille, Barcelona, Athens, Algiers, Cairo...).

Ecosystem responses exist at various ecological levels, but phytoplankton, which is the essential compartment of the aquatic food chain and the primary component of food chains, remains one of the most fragile components.

In this study, we propose to describe the ecosystem and examine the constituents of the coastal Algerian phytoplankton populations, which we divide 
into two: Alboran Sea and Algerian Basin. The aim is to determine the variations between the two areas, which will allow us to identify the basic characteristics of the two ecosystems on the Algerian coast.

An evaluation of environmental conditions in the two zones is the first stage of the work. The second step is to classify and determine the species of phytoplankton, making it easier to explain the diversity of populations within the group.

\section{MATERIAL AND METHODS}

The sampling campaigns took place on board of the oceanographic vessel "Grine Belkacem" in the Mediterranean on the Algerian coast during the spring of 2013, 2014 and 2015. A campaign is carried out by a group of researchers from the National Fisheries and Aquaculture Research and Development Center (CNRDPA).

\section{Study area}

The Alboran Sea is located in the western region of the Mediterranean Sea, between Spain, Morocco and Algeria. Its maximum width can reach $180 \mathrm{~km}$ in the east and a minimum of $14 \mathrm{~km}$ at the Strait of Gibraltar (Fig. 1). From west to east, the distance is approximately $350 \mathrm{~km}$ from the Strait of Gibraltar to the line between Cap de Gata (Almeria, Spain) and Cap Fegalo (Oran, Algeria). This imaginary line does not define a border, but a delineation of ecological processes and fluctuations in physical characteristics.

The Algerian Basin is in the center of the western Mediterranean Sea, between the Algerian coasts and the Balearic Islands on the west side and the island of Sardinia on the east side (Fig. 1). Its width can reach $280 \mathrm{~km}$ and its length of about $950 \mathrm{~km}$ (Riandey et al., 2005).

\section{Sampling}

A sampling strategy was developed by the researchers in charge of implementing the campaigns.

To study the dynamics of phytoplankton and the evaluation of environmental parameters, samples were taken. We also did hydrological analyses in situ during the campaigns. A CTD style probe is used to perform these measures (SAE-BID SBE19 plus). The GPS will report the location data of the sampling stations at the same time.

Samples preparation for the study of phytoplankton dynamics is done in two phases:

- the seawater sample for the qualitative and quantitative study of phytoplankton is carried out with a NISKIN PVC bottle with of 5 liters;

- fixation and storage: using Lugol's solution, the samples were immediately fixed. Then the samples are transported for analysis to the laboratory. In order to avoid discoloration and degradation of the cells, the bottles are placed in a cold, light-protected medium prior to their examination.

\section{Processing of phytoplankton samples and identification}

To homogenize the contents and to loosen any cells adhering to the walls and bottoms, the bottles holding the sample are softly shaken. Then a quantity of $100 \mathrm{ml}$ or $50 \mathrm{ml}$ (depending on the cell load

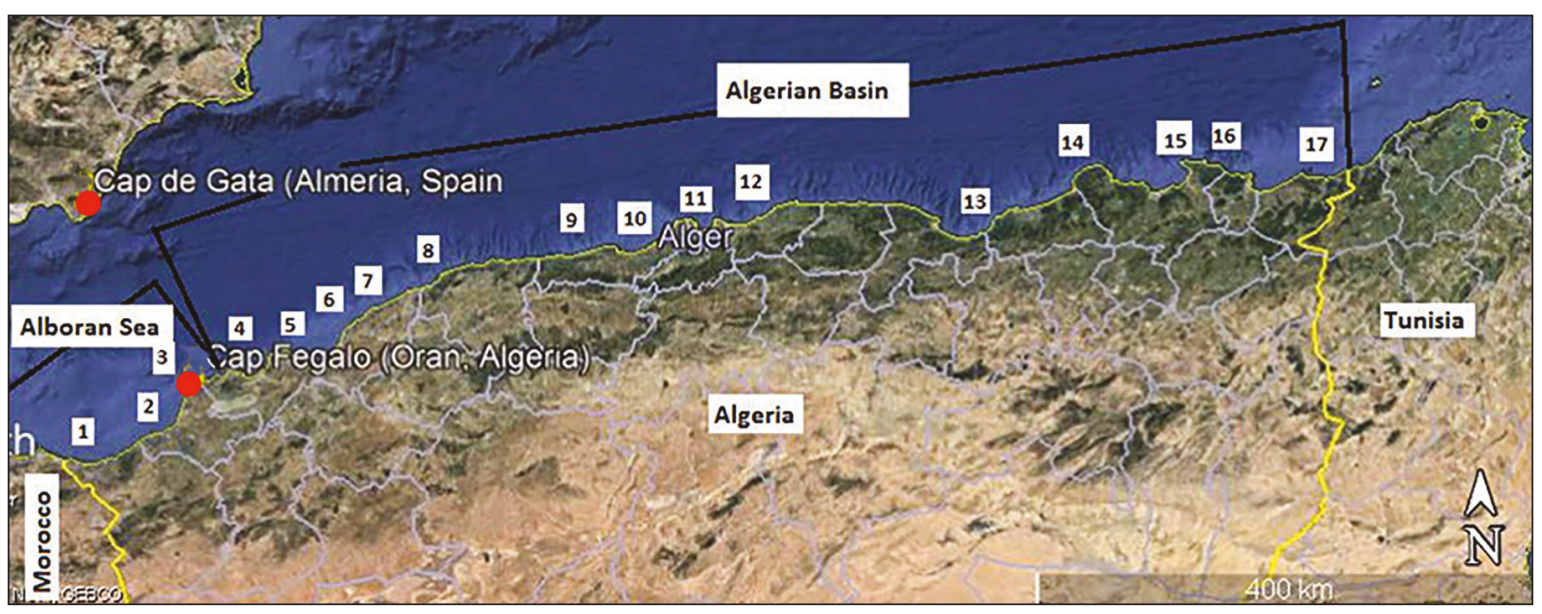

Figure 1. Positioning maps of sampling areas for the 2013, 2014 and 2015 campaign. 
of the sample) is poured into the sedimentation chambers (Utermohl tank).

The sedimentation time ranges from 24 to 72 hours, based on the sediment content (Druart \& Rimet, 2008).

Phytoplankton research was conducted in compliance with the criteria of the Reference Standard for Inverted Microscopy Enumeration of Phytoplankton - standard (NFEN 15.204, 2006) - corresponding to the Uthermôhl method (1958).

Observations were conducted under an inverted OPTKA type microscope with magnifications of 10 , 20 and 40. For identification and confirmation, a one-camera shooting scheme was really beneficial.

The classification and identification of phytoplankton species has been carried out at many systematic stages (genus, class and species).

We have made the specific identification of phytoplankton with the appropriate books and manuals (Meunier, 1910, 1915; Bérard-Therriault, 1999; Trégouboff \& Rose (1957).

\section{RESULTS AND DISCUSSION}

\section{Analysis of environmental parameters}

For the Mediterranean zone, the temperature reported on the Algerian coast during the three years of 2013, 2014 and 2015 is seasonal. The recorded spring average is $15.76 \pm 0.60{ }^{\circ} \mathrm{C}$. In time or space, it does not display any major difference.

During these three years, it remains regular. A maximum of $17.6^{\circ} \mathrm{C}$ was registered at Bou-Ismail Bay at Tipasa Station 10 in 2014 and a minimum of $14.79^{\circ} \mathrm{C}$ at Tizi-Ouzou Station 12 in 2013 (Fig. 2).

We note that on the Algerian coast, the seasonal temperatures for the spring time are about $15.7^{\circ} \mathrm{C}$. There are no major variations between Alboran Sea temperatures and Algerian Basin temperatures.

The average variations reported along the coast of Algeria remain in the order of $1{ }^{\circ} \mathrm{C}$, which helps us to say that the Algerian current flowing along the coast may be the cause of temperature standardization. In more or less protected areas such as the Bou-Ismail station 10 and Algiers bays station 11 , we also find small temperature changes...

These findings are consistent with the work already carried out in the region, such as Ignatiades et al. (2009) who found a temperature of $17.84 \pm$ $3.5^{\circ} \mathrm{C}$ in the Algerian Basin, Rossi (2008) which

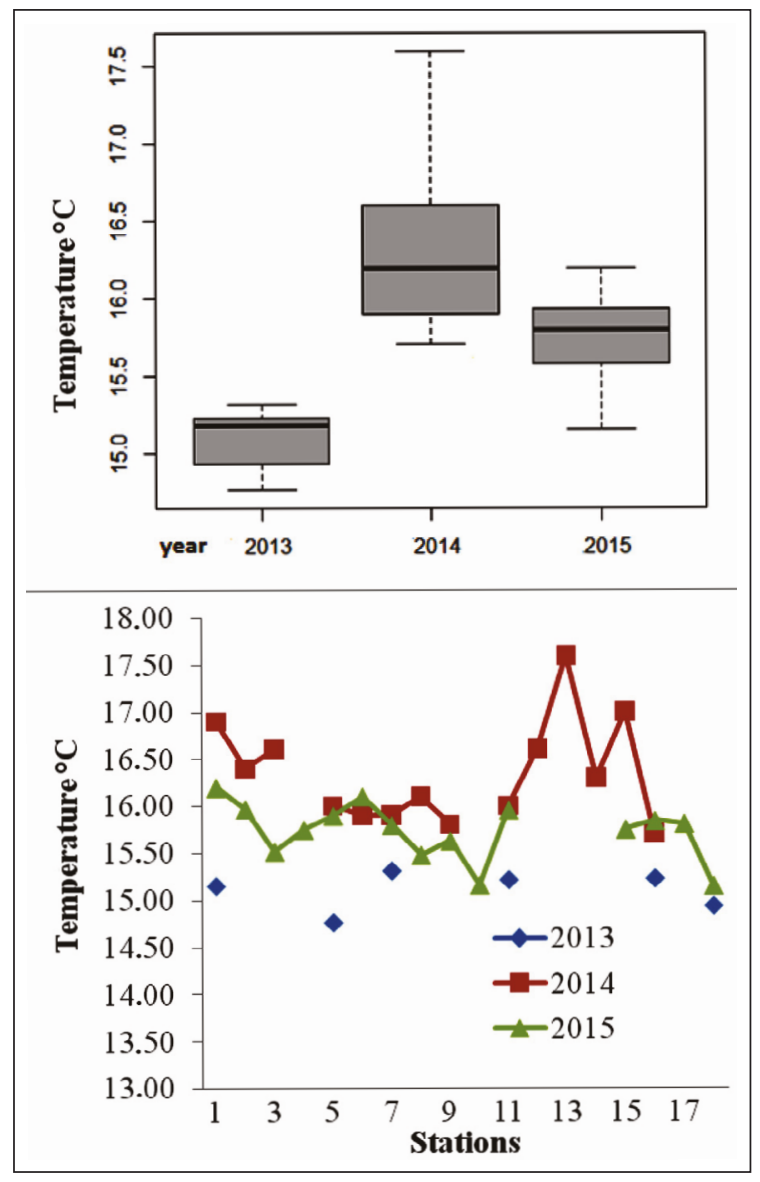

Figure 2. Variation of average temperatures during the years 2013, 2014 and 2015 of the Algerian coasts.

found a mean temperature of $13.6 \pm 1.7^{\circ} \mathrm{C}$ in the western Mediterranean, and Koukaras \& Nikolaidis (2004) who found a mean temperature of $17.64 \pm$ $6.5^{\circ} \mathrm{C}$ in the western Mediterranean Basin and 14.8 $\pm 4.9^{\circ} \mathrm{C}$ in the western Mediterranean basin.

The average salinity reported for the three years 2013, 2014 and 2015 on the Algerian coast is 36.48 \pm 0.3 PSU.

During 2014, we reported a maximum salinity of 37.14 PSU at the Tizi-Ouzou station and a minimum salinity of 35.68 at the Tlemcen station 1, respectively (Fig. 3). Overall, in time and space, the evolution of this salinity does not reveal major variations.

We note that salinity on the coast of Algeria stays constant during the three years 2013, 2014 and 2015, and does not display any fluctuation. In Fig. 3, which indicates very small frequency, this is very well illustrated.

We have a small salinity rise heading to EAST (Fig. 3). These findings indicate that the coast of 


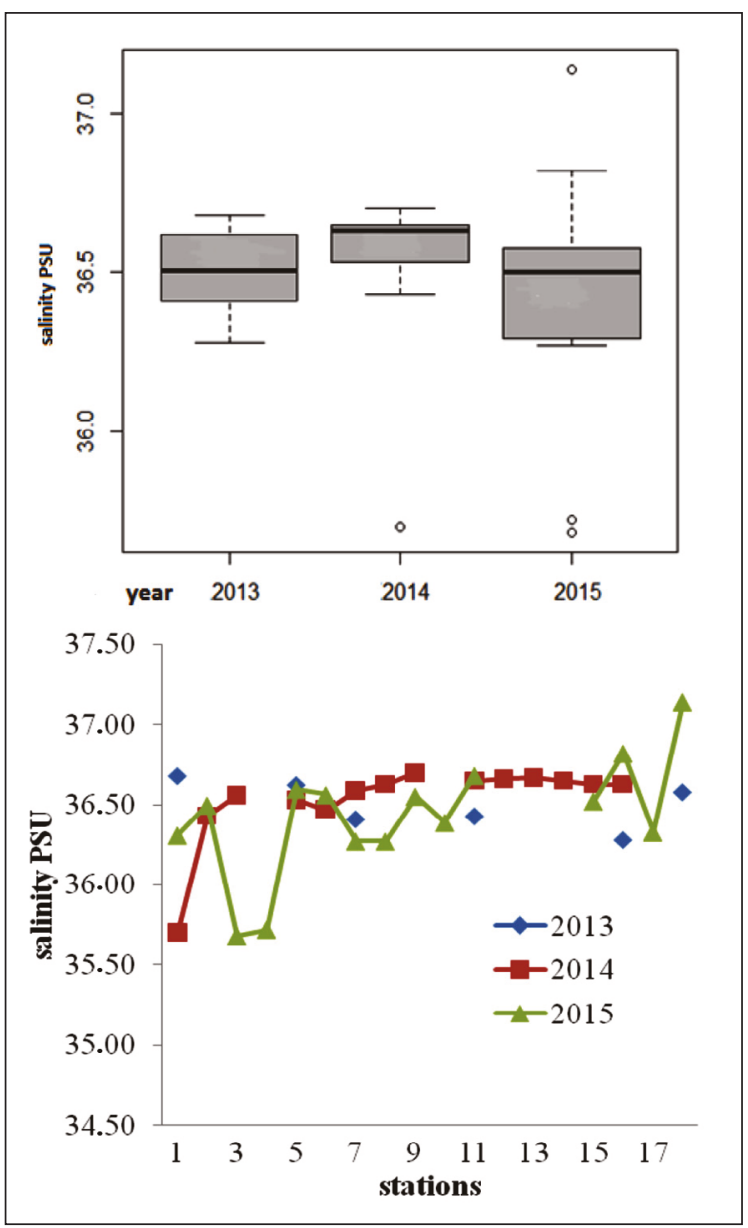

Figure 3. Variation in average salinities during the 2013, 2014 and 2015 campaigns on the Algerian coasts.

Algeria stays under the control of waters entering the Strait of Gibraltar flowing from the Atlantic Ocean. Tchernia (1978) suggests that exchanges in the Straits of Gibraltar between the less saline waters of the Atlantic ( $\mathrm{S}=36.2)$ and the more salty waters $(\mathrm{S}=38.4)$ originating from the Mediterranean at depth guarantee the maintenance of the degree of salinity in the western Mediterranean.

These findings are consistent with the work of other researchers like Koukaras \& Nikolaidis (2004) who found salinities in the western Mediterranean Sea of $37.00 \pm 0.79$ in 2001 and $37.01 \pm$ 1.19 in 2002. Ignatiades et al. (2009) found an average salinity in the Algerian basin of $37.43 \pm 0.75$. Berland et al. (1988) and Bethoux et al. (1998) suggest that the western Mediterranean basin is an area influenced by the flow of Atlantic waters across the Strait of Gibraltar. Tchernia (1978) showed that the maintenance of the degree of salinity in

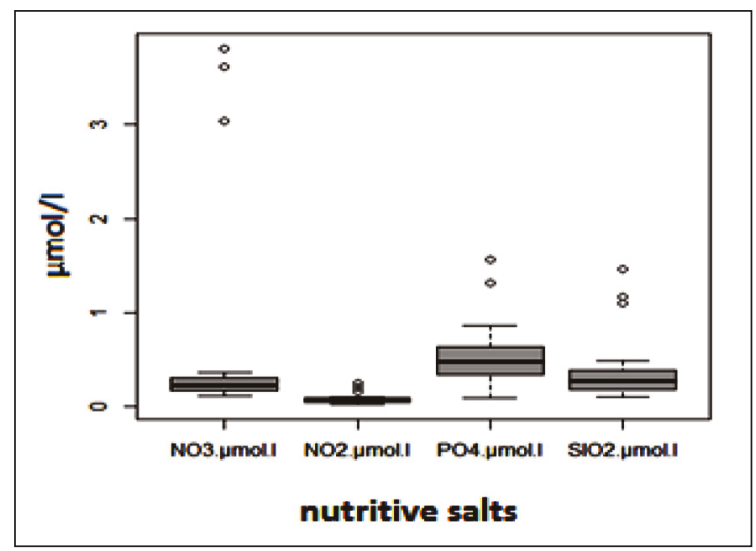

Figure 4. Variation in nutrient salt concentrations (year 2013).

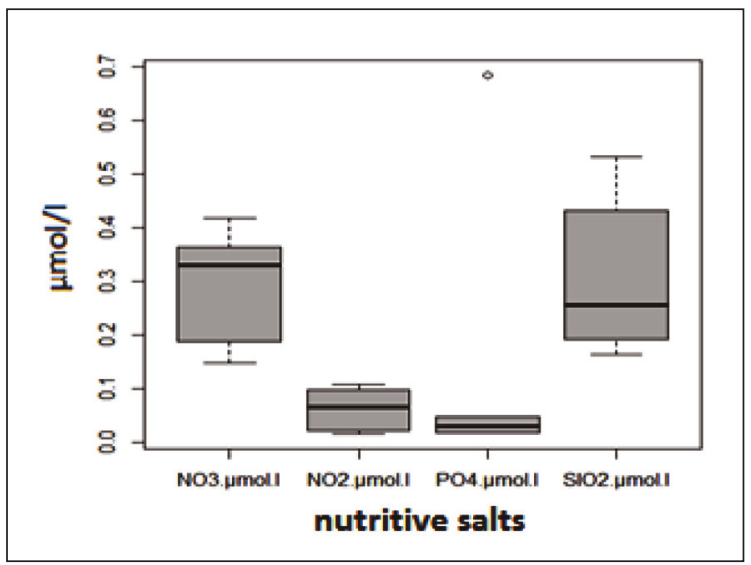

Figure 5. Variation in nutrient salt concentrations (year 2015).

the western Mediterranean Basin is assured by exchanges in Gibraltar involving less saline Atlantic waters $(\mathrm{S}=36)$.

With respect to chemical parameters, the concentrations of $\mathrm{NO} 2, \mathrm{NO} 3, \mathrm{PO} 4$ and $\mathrm{SIO} 2$ nutrient salts did not exceed $1 \mu \mathrm{mol} / 1$ during 2013, with the exception of a few stations, and did not vary significantly during 2013 (Figs. 4, 5). Lower concentrations of nitrites (NO2) are also found in addition to nitrates (NO3), while concentrations of orthophosphate $\mathrm{PO} 4$ are large.

We have average nitrate and nitrite concentrations of $0.2834 \pm 0.11$ and $0.0724 \pm 0.05 \mu \mathrm{mol} / \mathrm{l}$ at the Alboran sea level. We have average concentrations of $0.26 \pm 0.08$ and $0.13 \pm 0.04 \mu \mathrm{mol} / 1$ in the Algerian Basin. This will encourage one to conclude that in the Alboran Sea and the Algerian Basin, there is no substantial difference between the concentrations of nitrates and nitrites. 
The concentrations of nitrates and nitrites registered an average of $0.95 \pm 1.84 \mu \mathrm{mol} / 1$ and 0.09 $\pm 0.087 \mu \mathrm{mol} / \mathrm{l}$ respectively throughout 2013 and stayed more or less constant with weak variations, namely: a minimum of $0.12 \mu \mathrm{mol} / 1$ and a maximum of $8.66 \mu \mathrm{mol} / 1$ for nitrates; and a minimum of $0.021 \mu \mathrm{mol} / 1$ and a maximum of $0.12 \mu \mathrm{mol} / 1$ for nitrites, they stay more or less constant. No evidence of significant pollution is suggested by these findings.

Average nitrate and nitrite concentrations of 0.27 $\pm 0.12 \mu \mathrm{mol} / 1$ and $0.08 \pm 0.046 \mu \mathrm{mol} / 1$ respectively were reported throughout 2015. These concentrations, with slight variations not reaching $0.5 \mu \mathrm{mol} / 1$, remain low overall.

During 2013, the difference in phosphorus concentrations on the Algerian coast varied from a minimum of $0.08 \mu \mathrm{mol} / 1$ to a maximum of 1.98 $\mu \mathrm{mol} / \mathrm{l}$, with a reported average of $0.631 \pm 0.42$ $\mu \mathrm{mol} / \mathrm{l}$. We reported lower PO4 levels during 2015 , varying from a minimum of $0.002 \mu \mathrm{mol} / 1$ to a maximum of $0.051 \mu \mathrm{mol} / \mathrm{l}$. On the Algerian coast, the average estimated in 2015 is $0.031 \pm$ $0.012 \mu \mathrm{mol} / 1$.

Average orthophosphate concentrations of 0.09 $\pm 0.025 \mu \mathrm{mol} / \mathrm{l}$ were noted at the Alboran Sea level. The average concentration in the Algerian Basin is $0.062 \pm 0.012 \mu \mathrm{mol} / \mathrm{l}$.

The stoichiometric (N/P) ratio of dissolved inorganic nitrogen to the determined dissolved reactive phosphorus was compared with the standard Redfield ratio (N/P = 16) (Sterner \& Elser, 2002) (Figs. $6,7)$. We find low N/P ratio values that are consid- erably lower than the Redfield ratio. This shows the possible restriction of primary production induced during 2013 by the scarcity of nitrogen in the waters of the Alboran Sea and the Algerian Basin.

In 2015, on the other hand, in some regions of the Algerian coast, we found an inverted $\mathrm{N} / \mathrm{P}$ ratio with values exceeding 16 .

- We have a ratio approximating but not exceeding 16 in the Alboran Sea, which may mean a restriction of primary production caused by the lack of nitrogen in this area.

- We have N/P ratios $>16$ in the Algerian Basin: for example, in Oran station 5 and 6 (d'Arzew) we have a N/P ratio of 20.9; in Tipasa (Bou-Ismail and Mazafran) station 9 and 10 the N/P values are 25.4 and 25.9; in Boumerdes and de Jijel the N/P ratios are equal to 33.8 and 19.4 and 20.7 and finally in Annaba station 17 we have the most important N/P values (103.34). This may suggest a serious output limit caused by the shortage of phosphorus. Indeed, in these areas, we registered the lowest phosphorus values: $0.002 \mu \mathrm{mol} / 1$ and $0.009 \mu \mathrm{mol} / 1$.

The oligotrophic condition in the Mediterranean was primarily due to the restriction of phosphorus (P-PO4), according to some authors Krom et al. (1991) and Bethouxet et al. (1992).

An N/P ratio of 18.5 is found in the Algerian Basin (Ignatiades et al., 2009) and 36 is found in the western Mediterranean Sea (Koukaras \& Nikolaidis, 2004; Rossi, 2008).

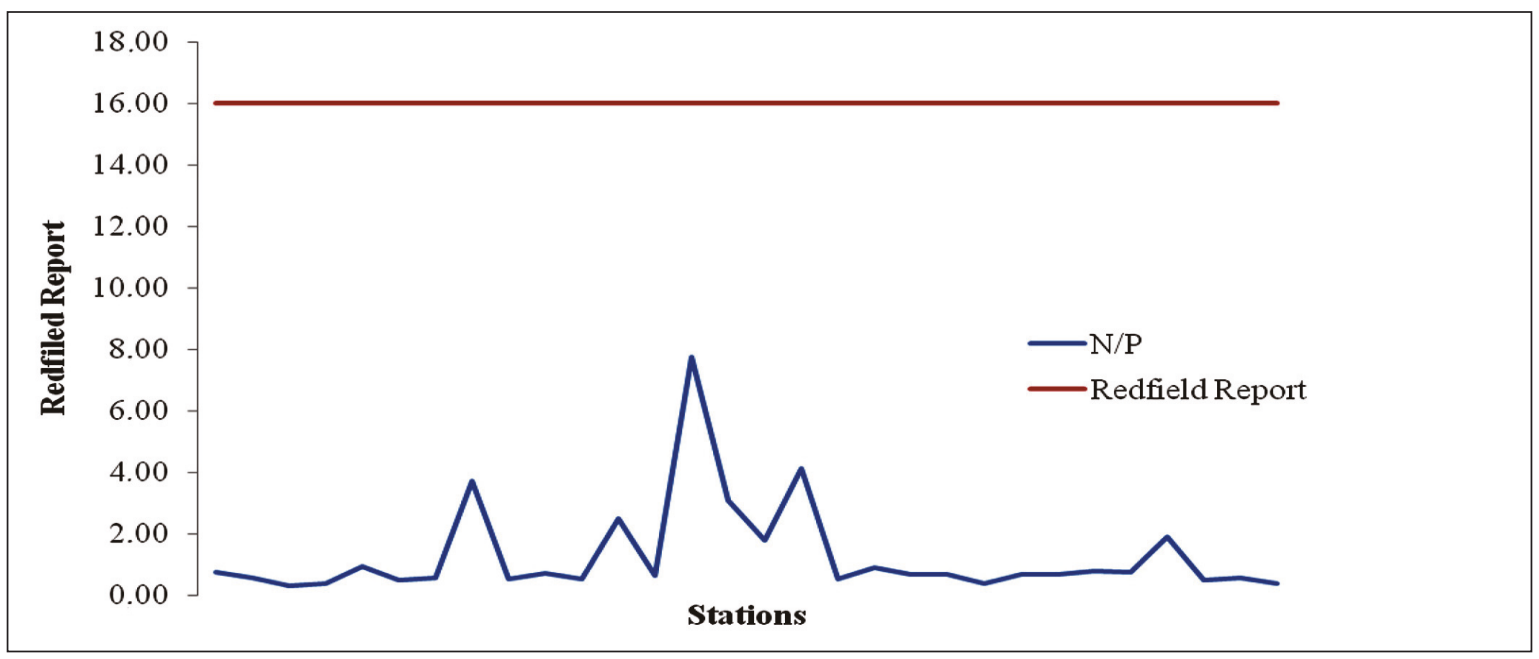

Figure 6. Representation of the Redfield Report by Redfield standards for the year 2013. 


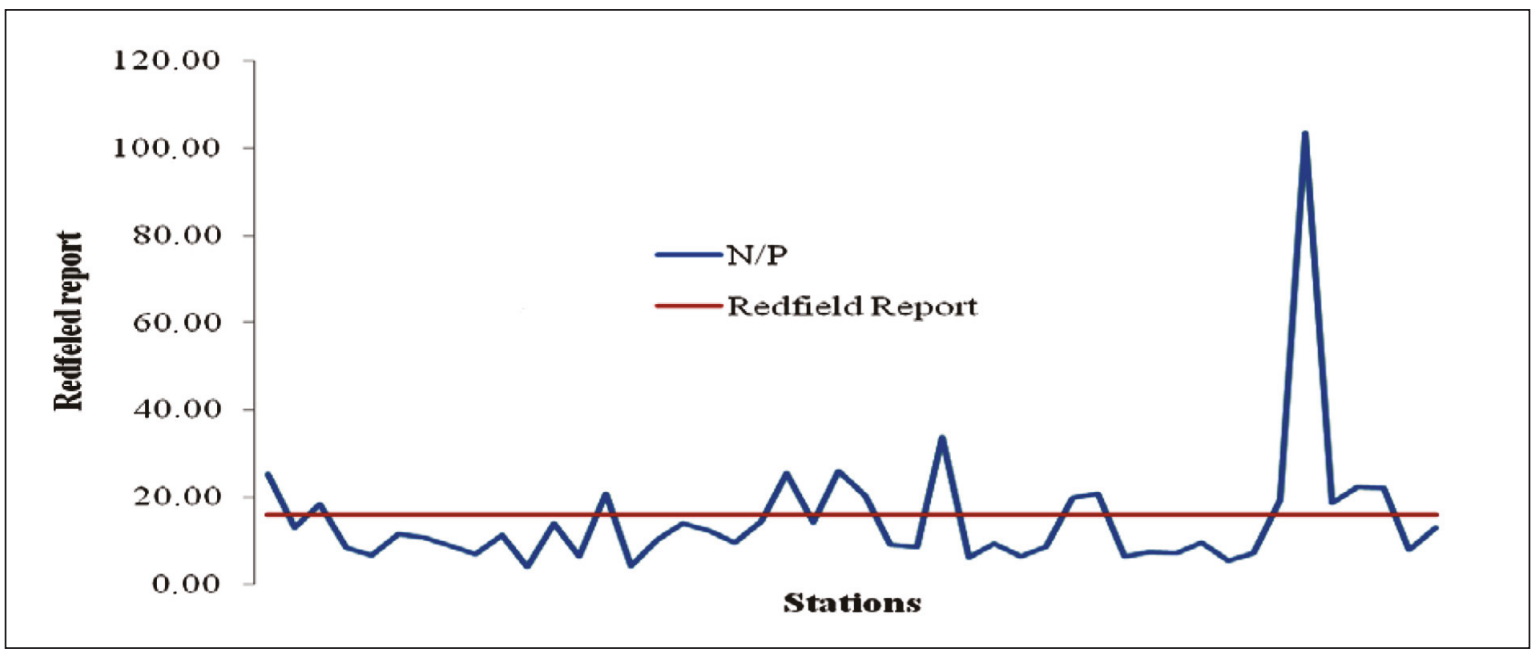

Figure 7. Representation of the Redfield report according to Redfield standards for the year 2015.

In surface waters, present silica acid levels are low and the average concentration is about $70 \mu \mathrm{Mol} / 1$ (Tréguer et al., 1995).

Silicate concentrations will range from a minimum of $0.107 \mu \mathrm{mol} / 1$ and a high of $2.69 \mu \mathrm{mol} / 1$ on the Algerian coast in 2013 (Fig. 7). The registered average is $0.47 \pm 0.54 \mu \mathrm{mol} / 1$.

SIO2 peaks are also reported at the stations of Tipasa $1.106 \mu \mathrm{mol} / \mathrm{l}$, Algiers $2.69 \mu \mathrm{mol} / \mathrm{l}$, and Skikda $1.14 \mu \mathrm{mol} / 1$.

These concentration peaks are noted to be in the same places where elevated concentrations (NO2, NO3, PO4) have been observed and which may be areas of influence of some rivers, such as Mazafran, El Harrache, El Hamiz and Zhour.

In 2015, lower SIO4 content was registered, varying from a minimum of $0.13 \mu \mathrm{mol} / 1$ to a maximum of $0.631 \mu \mathrm{mol} / \mathrm{l}$. The average estimated in 2015 for the whole Algerian coast is $0.32 \pm 0.14 \mu \mathrm{mol} / \mathrm{l}$.

During the spring of the years 2013 to 2015 , a physico-chemical analysis of the waters of the Algerian coast made it possible to determine the critical physico-chemical conditions that we find in these two areas of the Mediterranean (Alboran Sea and Algerian Basin).

The Algerian Basin waters and the Alboran Sea remain under the control of temperature and salinity exchanges with the Atlantic Ocean. The nutrient content of all the observed variables (nitrites, nitrates, phosphorus and silicate) is poor and there is no substantial distinction between the waters of the Algerian Basin and those of the Alboran Sea.

\section{Qualitative phytoplankton analysis}

A study of the composition of the Algerian coastal phytoplankton population was carried out over the spring period of three consecutive years (2013, 2014 and 2015).

The data were analyzed under two distinct aspects: a spatial perspective in which we concentrated on the characterization of the Alboran Sea and Algerian Basin phytoplankton communities, and a temporal aspect in the two zones with changes that can be observable from year to year.

To this end, we have an estimation of the richness and taxonomic composition of species, the diversity of species, as well as the spatial and temporal distribution and abundance of species during this time.

The inventory of the species found is for macrophytoplankton (mainly Diatoms and Dinoflagellates). 361 species were counted for the three years, 2013, 2014 and 2015, putting many genera together.

With 60.11 percent of species, Dinoflagellates are the most described in terms of number of species, while Diatoms account for 38.50 percent and just 1.39 percent for other species.

We have a specific richness of 211 species in the Alboran Sea, mostly represented by the dominant classes (diatoms and dinoflagellates), 61.14 percent dinoflagellates and 37.91 percent diatoms have been noted in this region, and the other species represent just 0.95 percent. 


\begin{tabular}{|c|l|c|c|c|c|}
\hline Years & Zone of study & Specific richness & Diatoms \% & Dinoflagellates \% & Others \% \\
\hline \multirow{3}{*}{2013} & the whole coast & 280 & 39.59 & 59.59 & 1.43 \\
\cline { 2 - 6 } & Alboran Sea & 34 & 61.11 & 39.89 & 00 \\
\cline { 2 - 6 } & Algerian basin & 266 & 33.98 & 64.48 & 1.54 \\
\hline \multirow{3}{*}{2014} & the whole coast & 183 & 39.82 & 59.77 & 0.41 \\
\cline { 2 - 6 } & Alboran Sea & 114 & 40.22 & 59.34 & 0.44 \\
\cline { 2 - 6 } & Algerian basin & 129 & 39.46 & 60.15 & 0.38 \\
\hline \multirow{3}{*}{2015} & the whole coast & 158 & 30.29 & 68.25 & 1.46 \\
\cline { 2 - 6 } & Alboran Sea & 92 & 25.21 & 74.79 & 00 \\
\cline { 2 - 6 } & Algerian basin & 76 & 34.19 & 63.23 & 2.58 \\
\hline
\end{tabular}

Table 1. Overview of species richness and percentages in 2013, 2014 and 2015 of dinoflagellates and diatoms.

We have a specific richness of 291 species in the Algerian Basin of 59.45 percent dinoflagellates and 39.18 percent diatoms, with the other species comprising just 1.37 percent.

The specific wealth increased from 280 species in 2013; 183 in 2014 to 158 in 2015. For all large populations, the proportions of dinoflagellates and diatoms remain similar. We see a domination of dinoflagellates that ranges from 59 to 74 percent, relative to diatoms, which constitute 25 to 40 percent of phytoplankton organisms. With the exception of the Alboran Sea year 2013, where we have a 61 percent domination of diatoms (Table 1).

The relation between our observations and those of the bibliography provides:

- 216 species, including 48 diatoms, 112 dinoflagellates and 56 coccolithophores, were identified by Ignatiades et al. (2009).

- Casas et al. (1998) identified 205 species, including 144 dinoflagellate species, and 61 species representing other groups (Table 2).
Our results are very similar to those of Casas et al. (1998) and Ignatiades et al. (2009), we note. Indeed, the specific richness we have noticed on the coasts of Algeria (the Alboran Sea and the Algerian Basin) is very similar to that of the two authors.

Our observations are consistent with the work conducted in the western Mediterranean. Indeed, the dominance in the Algerian Basin of diatoms and dinoflagellates is recorded by Smayda \& Reynolds (2001).

In the western Mediterranean, the dominance of dinoflagellates over diatoms is stated by other writers such as Kimor (1983), Margalef (1985), Berland et al. (1988), Halim, (1990), Gotsis-Skretas et al. (1999), Gomez et al. (2003), and Boudjenah et al. (2019).

We also note that in the eastern and western stations, dinoflagellates were the most frequent in 2014 and 2015, while the number of diatom species was higher in the west in 2013.

\begin{tabular}{|l|c|c|c|c|}
\hline & Number of species & Diatoms & Dinoflagellates & Others \\
\hline Ignatiades et al., 2009 & 216 & $22 \%$ & $52 \%$ & $26 \%$ \\
\hline Casas et al., 1998 & 205 & - & $70 \%$ & - \\
\hline Present work Algerian coast & 361 & 38.50 & 60.11 & 1.39 \\
\hline Present work Algerian coast & 211 & 37.91 & 61.14 & 0.95 \\
\hline Present work Algerian coast & 291 & 39.18 & 59.45 & 1.37 \\
\hline
\end{tabular}

Table 2. Comparison of the distribution and composition of the specific wealth of the Algerian coast with the bibliography in percentages. 


\section{CONCLUSIONS}

This study is of considerable importance to better understand the the ecological and phytoplankton condition of the Algerian coast during the beginning of the spring season of the three following years, 2013, 2014 and 2015,

We recorded a mean seasonal temperature and salinity, respectively, on the Algerian coasts of about $15.76 \pm 0.60^{\circ} \mathrm{C}$ and $36.48 \pm 0.3 \mathrm{PSU}$

We did not note any significant differences between the Alboran Sea and the Algerian Basin.

Mean nutrients concentrations were recorded as follows: nitrates of $0.273 \pm 0.130 \mu \mathrm{mol} / \mathrm{l}$; nitrites of $0.085 \pm 0.065 \mu \mathrm{mol} / 1$; phosphorus, of $0.286 \pm$ $0.395 \mu \mathrm{mol} / 1$ and silicates of $0.375 \pm 0.366 \mu \mathrm{mol} / 1$, in the Algerian Basin and the Alboran Sea.

We identified and determined 361 species of phytoplankton

Dinoflagellates are the most represented with $60.11 \%$ of species, diatoms represent $38.50 \%$ and other species represent only $1.39 \%$.

In general, our observations were in line with the work already performed in the western Mediterranean Basin (the Algerian Basin). They make a contribution complimentary to previous work carried out in the region.

Information of the ecological condition helps one to provide indicators on the trophic stages of the coast of Algeria (Alboran Sea and Algerian Basin).

\section{REFERENCES}

Bérard-Therriault L., Poulin M. \& Bossé L., 1999. Guide d'identification du phytoplancton marin de l'estuaire et du Golfe du Saint-Laurent. NRC Press (Canada), $387 \mathrm{pp}$.

Berland B.R., Benzhitski A.G. \& Burlakova Z.P., 1988. Conditions hydrologiques estivales en Méditerranée, répartition du phytoplancton et de la matière organique. Oceanologica Acta, Special issue Open Access version, pp. 163-177.

https://archimer.ifremer.fr/doc/00267/37814/35895.pdf

Bethoux J.P., Morin P. \& Madec C., 1992. Phosphorus and nitrogen behavior in the Mediterranean Sea. Deep-Sea Research part II, 39: 1641-1654. https://doi.org/10.1016/0198-0149(92)90053-V

Béthoux J.P., Morin P., Chaumery C., Connan O., Gentili B. \& Ruiz-Pino D., 1998. Nutrients in the Mediterranean Sea, mass balance and statistical analysis of concentrations with respect to environmental change. Marine Chemistry, 63: 155-169. https://doi.org/10.1016/S0304-4203(98)00059-0

Boudjenah M., Mokrane Z. \& Soualili D., 2019. Diversity of Phytoplanktonic populations along the Algerian coastline. Biodiversity Journal, 10: 81-92. https://doi.org/10.31396/Biodiv.Jour.2019.10.2.81.92

Casas B., Varela M. \& Bode A., 1998. Seasonal succession of phytoplankton species on the coast of A Coruña (Galicia, northwest Spain). Boletín del Instituto Español de Oceanografía, 15 (1999): 413-429. https://www.researchgate.net/publication/215739034

Druart J-C. \& Rimet F., 2008. Protocoles d'analyse du phytoplancton de l'INRA: Prélèvement, dénombrement et biovolumes. INRA, $97 \mathrm{pp}$.

Gotsis-Skretas O., Pagou K. \& Moraitou-Apostolopoulou M., 1999. Seasonal horizontal and vertical variability in primary production and standing stocks of phytoplankton and zooplankton in the Cretan Sea and the Straits of the Cretan Arc (March 1994-January 1995). Progress In Oceanography, 44: 625-649. https://doi.org/10.1016/S0079-6611(99)00048-8

Gomez E., 2003. Checklist of Mediterranean free-living dinoflagel-lates. Botanica Marina, 46: 215-242. https://doi.org/10.1515/BOT.2003.021

Halim Y., 1990. On the potential migration of IndoPacific plankton through the Suez Canal. Bulletin de l'Institut océanographique de Monaco, 7: 11-27. https://www.scopus.com/record/display.uri?eid=2-s2.00002304392 \& origin $=$ inward\& txGid $=a b 5 a 8042$ bb75aa 2b9636251886f283eb

Haury L.R., McGowan J.A. \& Wiebe P.H., 1978. Patterns and processes in time-space scales of plankton distributions. In: Steele J.H. (Ed.), Spatial pattern in plankton communities. Plenum Press, New York, pp. 277-327. https://doi.org/10.1007/BF01313168

Ignatiades L., Gotsis-skretas O., Pagou K. \& krasakopoulou E., 2009. Diversification of phytoplankton community structure and related parameters along a large scale longitudinal east-west transect of the Mediterranean Sea. Journal of Plankton Research, 31: 411-428. https://doi.org/10.1093/plankt/fbn124

Koukaras K. \& Nikolaidis G., 2004. Dinophysis blooms in Greek coastal waters (Thermaikos Gulf, NW Aegean Sea). Journal of Plankton Research, 26: 445-457. https://doi.org/10.1093/plankt/fbh042

Kimor B., 1983. Distinctive features of the phytoplankton of the eastern Mediterranean. Annales de l'Institut océanographique de Paris, 50: 97-106. http://aquaparadox.obs-vlfr.fr/html/PFD/Taxonomic\% 20Monographs/Kimor1990.pdf

Krom M.D., Kress N. \& Brenner S., 1991. Phosphorus limitationof primary productivity in the eastern Medi- 
terranean Sea. Limnology and Oceanography, 36: 424-432. https://doi.org/10.4319/1o.1991.36.3.0424

Margalef R., 1985. Environmental control of the mesoscale distribution of primary producers and its bearing to primary production in the western Mediterranean. Mediterranean Marine Ecosystems. NATO Conference Series. Vol. 8. Plenum Press, London, pp. 213-230. https://link.springer.com/chapter/10.1007/978-14899-2248-9_10

Maria E. \& Meave-Del Castillo M., 2010.

Trégouboff M. \& Rose M., 1957. Manuel de planctonologie méditerranéenne Tome I et II . Paris, Centre national de la recherche scientifique, $227 \mathrm{pp}$.

Meunier A., 1910. Microplankton des Mers de Barents et de Kara. Duc d'Orléans. Campagne arctique de 1907. Imprimerie scientifique Charles Bulens: Bruxelles. $355+$ atlas (XXXVII plates) pp.

Meunier A., 1915. Microplankton de la Mer Flamande. 2eme partie, les Diatomacées (suite). Mémoires de Musée Royal d'Histoire Naturelle de Belgique, 7: $1-372$.

Riandey V., Champalbert G., Carlotti F., Taupier-Letage I. \& Thibault-Botha D., 2005. Zooplankton distribution related to the hydrodynamic features in the Algerian Basin (western Mediterranean Sea) in summer
1997. Deep Sea Research Part I. Oceanographic Research Papers, 52: 2029-2048. https://doi.org/10.1016/j.dsr.2005.06.004

Rossi N., 2008. Ecologie des communautés planctoniques méditerranéennes et étude des métaux lourds (Cuivre, Plomb, Cadmium) dans différents compartiments de deux écosystèmes côtiers (Toulon, France). Thèse de doctorat, Université du sud Toulon-Var, 201 pp. https://tel.archives-ouvertes.fr/tel-00439972/document Smayda T.J. \& Reynolds C.S., 2001. Community assembly in marinephytoplankton: application of recentmodels to harmful dinoflagellate blooms. Journal of Plankton Research, 23: 447-461. https://doi.org/10.1093/plankt/23.5.447

Tchernia P., 1978. Océanographie régionale : description physique des océans et des mers. Ecole nationale supérieure des techniques avancées, Paris, $257 \mathrm{pp}$.

Tréguer P., Nelson D.M., Van Bennekom A.J., DeMaster D.J., Leynaert A. \& Quéguiner B., 1995. The silica balance in the world Ocean: a reestimate. Science, 268: 375-379.

https://doi.org/10.1126/science.268.5209.375

Utermöhl H., 1958. Zur Vervollkommnung der quantitativen Phytoplankton-Method. International Association of Theoretical and Applied Limnology, 9: 1-39. https://doi.org/10.1080/05384680.1958.11904091 
